\title{
BIOCHEMICAL GENETICS OF TIGER SHRIMP Penaeus monodon: DESCRIPTION OF ELECTROPHORETIC DETECTABLE LOCI
}

\author{
Ketut Sugama*), Haryanti"and Fuad Cholik**)
}

\begin{abstract}
As part of a search for biochemical genetic markers for tiger shrimp, Penaeus monodon, wild shrimp were collected from the coastal waters of Aceh, Bali and Sumbawa, (Nusa Tenggara Barat). Tissues samples of hepatopancreas and abdominal muscle from these were analyzed by starch gel electrophoresis. Specific staining for 13 enzymes resolved 21 loci, 6 of which were polymorphic (i. e., EST-2, GPI, IDH, LDH-1, MDH-1 and $\alpha$-GPD). The observed number of phenotypes for respective loci agreed well with HardyWeinberg expectations. The genetic basis of each polymorphism is discussed. Most of the polymorphic loci were dimeric (GPI, IDH, MDH and $\alpha$-GPD) except for EST-2 was monomeric and LDH-1 was tetrameric. The genetic variability in Penaeus monodon was indicated by the number of polymorphic loci, heterozygosity $(\mathrm{H})$ and number of alleles per locus $(\mathrm{N})$ was relatively low compared to other marine organisms. The values of $\mathbf{H}$ and $\mathrm{N}$ for this species ranged from 0.025 to 0.047 and 1.381 to 1.528 respectively. This study suggest the use of GPI, IDH and MDH loci as genetic markers in any genetic improvement program.
\end{abstract}

\section{KEYWORDS: Biochemical genetic, electrophoretic, Penaeus monodon.}

\section{INTRODUCTION}

Tiger shrimp, Penaeus monodon, is an important species in both capture fisheries and coastal aquaculture in Indonesia. An estimated 300.000 ha. of brackishwater pond are in use, mostly converted from mangrove area (Chamberlain, 1991). Approximately $90 \%$ of the Penaeus monodon fry required for pond stocking originate from hatcheries. In 1994, 142 hatcheries were operating in Indonesia.

Although Penaeus monodon farms the basic of the largest penaeid aquaculture industry in Indonesia, little is known of it genetics. Some work has been carried out on the hybridization between $P$. stylostris and $P$. monodon (Benzie et $a l ., 1975)$ and some quantitative genetic data of $P$. marguiensis (Goswani et al., 1986) and $P$. monodon (Sugama et al., 1993) are currently available, but virtually no biochemical genetic research has been done on $P$. monodon.
Recently, electrophoretically - detectable enzyme or protein variants (biochemical genetic variants or genetic variant) have been used as biochemical genetic markers in biological research. Many workers have shown that enzymes and proteins are useful genetic markers for fisheries biology, aquaculture and breeding studies (Sbordoni et al., 1986; Busack, 1988; Taniguchi and Sugama, 1990; Sugama et al., 1992; Taniguchi et al., 1994). Sbordoni et al. (1986) have summarized the importance of detecting genetic variance in $P$. japonicus in hatchery using electrophoretic markers in order to avoid inbreeding. Wohlforth and Hulata (1983) have obtained genetic improvement in tilapia using electrophoretic markers.

The objective of this study is to provide genetic interpretation for the variability patterns of electrophoretically detectable enzymes and proteins of wild stock tiger shrimp, Penaeus monodon. The technique will be useful for monitoring the genetic variability and popula-

\footnotetext{
*) Researcher of the Gondol Research Station for Coastal Fisheries

*) Researcher of the Central Research Institute for Fisheries
} 
tion structure of wild stocks, genetic change and inbreeding in hatchery stocks and as biochemical markers in selective breeding for genetic improvement programmes.

\section{MATERIAL AND METHODS}

\section{Sample Preparation}

Shrimp with body length from 22.4 to 26.8 $\mathrm{cm}$, were collected from Cempi Bay Dompu, Sumbawa, (Nusa Tenggara Barat), from the coastal waters of Aceh, and Negara (Bali). In each case 100 specimens were taken. The shrimps were transported alive to Gondol Research Station, killed and immediately stored at- $20^{\circ} \mathrm{C}$ until used. The maximum storage time was 2 weeks. Small portions of abdominal muscle and hepatopancreas tissues were dissected and placed in individual plastic tubes or multi-well disposable trays (Wako-Lab). The tissues were extracted with mixed $\mathrm{MgCl}_{2} 0.005$ $\mathrm{M}$ and $\mathrm{KCN} 0.005 \mathrm{M}$. Filter paper (5 x $10 \mathrm{~mm})$ were saturated with extract, lightly blotted and applied to the gel.

\section{Electrophoresis}

The starch-gel electrophoretic and staining methods used for detection of biochemical markers followed the procedures described by (Sugama 1988; Sugama et al., 1992). Gels were prepared with 10-12\% (depending on batch) of hydrolized starch (Connaught Lab. Sigma Chemical Co.) Two buffer systems used were Tris Citric-acid pH 8.0 (TC-8) and Citric-Acid Aminopropyl Morpholine pH-6 (CAMP-6). Electrophoresis was carried out for 4 hours at 4 $\mathrm{MA} / \mathrm{cm}^{2}$.

The enzymes and proteins examined, loci detected and the appropriate buffer system and the tissue giving best resolution are given in Table 1 .

\section{Interpretation of Banding Pattern}

Locus and allele nomenclature followed the basic method of Alledorf and Utter (1979). Multiple loci encoding a single enzyme or pro- tein were designated with a hyphenated number indicating the relative migration of their product, the least anodal being designated 1 . Alleles designated by the proportional migration distances of their products relative to that of the common allele, which was arbitrarily designated 100 , and other alleles were given numbers that indicated their mobility relative to that of the common allele.

\section{Interpretation of Data}

Alleles frequencies $(\mathrm{P})$ were derived from the number of genotypes observed from electrophoretic analysis using the expression: $\mathrm{P}=(2 \mathrm{Ho}+$ $\mathrm{He}) / 2 \mathrm{~N}$, where, $\mathrm{Ho}=$ Number of homozygotes; $\mathrm{He}=$ Number of heterozygotes and $\mathrm{N}=$ Number of individuals examined.

In the randomly mating population containing known allele frequencies, the expected proportion of each genotype (homo and heterozygotes) is predicted by the Hardy-Weinberg expectation. Deviation from the expected proportion generally indicates the presence of a mixed population which is not the product of random mating. Deviation from Hardy-Weinberg expectation at each locus was tested for significance using the log-likelihood Chi-square test $\left(\mathrm{X}^{2}\right)$ for goodness of fit (Sokal and Rohlf, 1981) with degree of freedom equal to the number of expected genotypes minus the number of alleles.

Heterozygosity estimates were calculated both as the observed proportion of heterozygotes and as the proportion expected through the Hardy-Weinberg expectation.

A locus was considered to be polymorphic if the most common allele was equal to or less than 0.99 .

\section{RESULT AND DISCUSSION}

Enzymes and proteins tested, loci detected, tissues assayed and buffer systems giving the clearest resolution are shown in Table 1 . The enzymes or proteins were located as stained zones of activity after electrophoretic separation in gel media (Fig. 1). Each stained zone was attributed to a genetic locus. 
Enzymes appearing as a single zone of activity are assumed to represent the product of single genetic loci. Those with two or more well separated zones of activity are assumed to be the products of two or more loci.

Multiple loci have been numbered with a suffix in order of decreasing anodic mobility. The locus with the most anodal migration is designated number one, the next two and so on. The most common allele is designated 100 and other alleles are given numbers that indicate their mobility relative to that of the common allele (Table 2 and Fig. 1). Cathodal systems are designated in similar way but are given a negative sign. Loci in which all samples tested appeared as a single band have been classified as monomorphic. Those loci revealing electrophoretic variants have been classified as polymorphic.

Among 21 loci examined, six loci were polymorphic EST, GPI, IDH, LDH-1, MDH-1 and $\alpha$ GPD. Zymograms of the polymorphic loci are given in Fig. 1. Brief descriptions of the poly. morphic loci are given below.

Table 1. A summary of enzymes and protein examined locus designations, tissue and buffer used in Penaeus monodon.

\begin{tabular}{|c|c|c|c|c|}
\hline $\begin{array}{l}\text { Enzyme/Protein } \\
\text { (Abbreviation) }\end{array}$ & Locus & Tissue1) & Buffer2) & $\begin{array}{c}\text { Poly- } \\
\text { morphism3) }\end{array}$ \\
\hline Alcohol dehydogenase (ADH) & $\mathrm{ADH}$ & $\mathrm{hp}$ & CAPM & M \\
\hline \multirow[t]{2}{*}{ Aspartate dehydrogenase (AAT) } & AAT-1 & $\mathrm{m}$ & CAPM & M \\
\hline & AAT-2 & $\mathrm{m}$ & CAPM & M \\
\hline \multirow{2}{*}{ Esterase (EST) } & EST-1 & $\mathrm{hp}$ & CAPM & M \\
\hline & EST-2 & hp & CAPM & $\mathrm{P}$ \\
\hline Glucosephosphate isomerase (GPI) & GPI & $\mathrm{m}$ & CAPM & $\mathrm{P}$ \\
\hline $\begin{array}{l}\propto \text {-Glycerophosphate dehydrogenase }(\alpha- \\
\text { GPD) }\end{array}$ & $\propto-G P D$ & $\mathrm{~m}$ & $\mathrm{TC}$ & $\mathrm{P}$ \\
\hline Isocitrate dehydrogenase (IDH) & IDH & $\mathrm{m}$ & CAPM & $\mathrm{P}$ \\
\hline \multirow{2}{*}{ Lactate dehydrogenase (LDH) } & LDH-1 & $\mathrm{m}$ & CAPM & $\mathrm{P}$ \\
\hline & LDH-2 & $\mathrm{m}$ & CAPM & M \\
\hline \multirow[t]{2}{*}{ Malate dehydrogenase $(\mathrm{MDH})$} & $\mathrm{MDH}-1$ & $\mathrm{~m}$ & CAPM & $\mathrm{P}$ \\
\hline & $\mathrm{MDH}-2$ & $\mathrm{~m}$ & CAPM & M \\
\hline Malic enzyme (ME) & $\mathrm{ME}$ & $\mathrm{m}$ & $\mathrm{TC}$ & M \\
\hline \multirow[t]{2}{*}{ Phosphoglucomutase (PGM) } & PGM-1 & $\mathrm{m}$ & CAPM & M \\
\hline & PGM-2 & $\mathrm{m}$ & CAPM & $\mathrm{M}$ \\
\hline $\begin{array}{l}\text { 6-Phosphogluconate dehydrogenase (6- } \\
\text { PGD) }\end{array}$ & 6-PGD & $\mathrm{m}$ & $\mathrm{TC}$ & M \\
\hline \multirow{4}{*}{ Sarcoplasmic protein (SP) } & SP-1 & $\mathrm{m}$ & $\mathrm{TC}$ & M \\
\hline & SP-2 & $\mathrm{m}$ & $\mathrm{TC}$ & M \\
\hline & SP-3 & $\mathrm{m}$ & $\mathrm{TC}$ & M \\
\hline & SP-4 & $\mathrm{m}$ & $\mathrm{TC}$ & M \\
\hline Sorbitol dehydrogenase (SDH) & $\mathrm{SDH}$ & hp & $\mathrm{TC}$ & M \\
\hline
\end{tabular}

1. hp=Hepatopancreas; $\mathrm{m}=$ Abdominal muscle

2. CAPM=Citric acid-aminopropyl morpholine $\mathrm{pH}-6$; $\mathrm{TC}=$ Tris citric acid $\mathrm{pH}-8$

3. $\mathrm{P}=$ Polymorphi; $\mathrm{M}=$ Monomorphic 
Sugama, K.; Haryanti and Cholik, F.

Allele


$\mathrm{MDH}-1$


Figure 1. Electrophoretic pattern of six polymorphic loci in Penaeus monodon. 


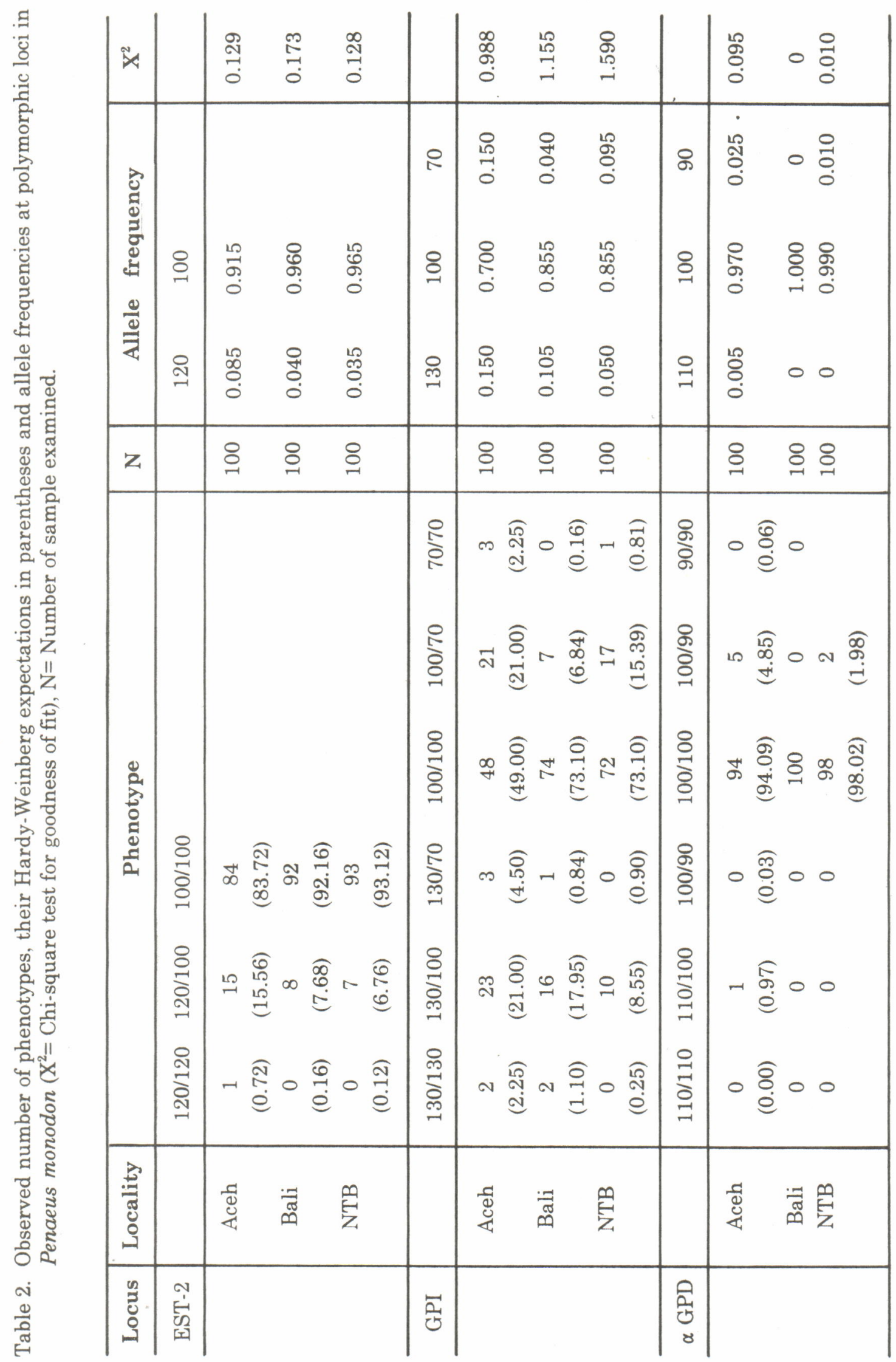


Sugama, K.; Haryanti, and Cholik, F.

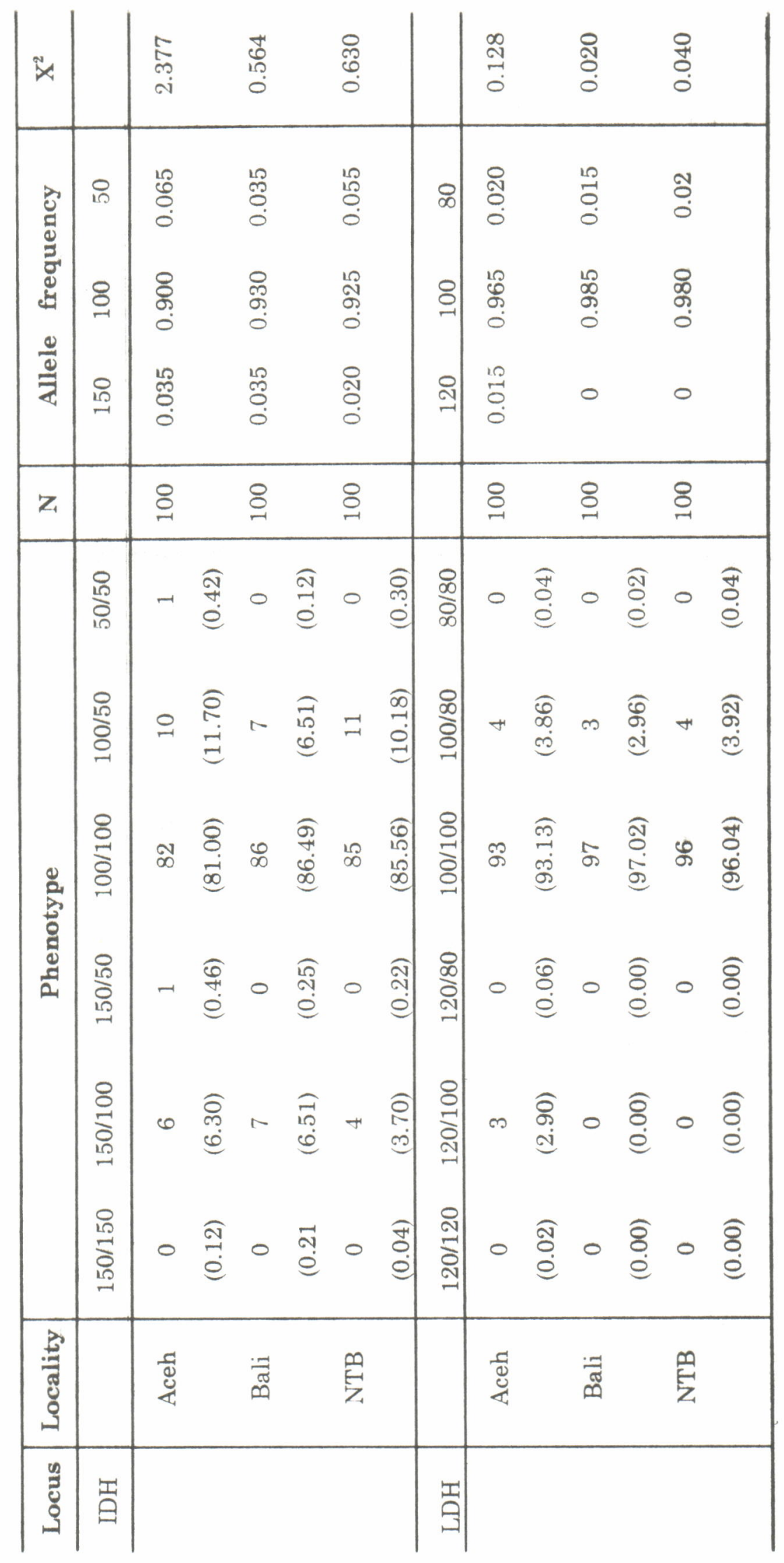




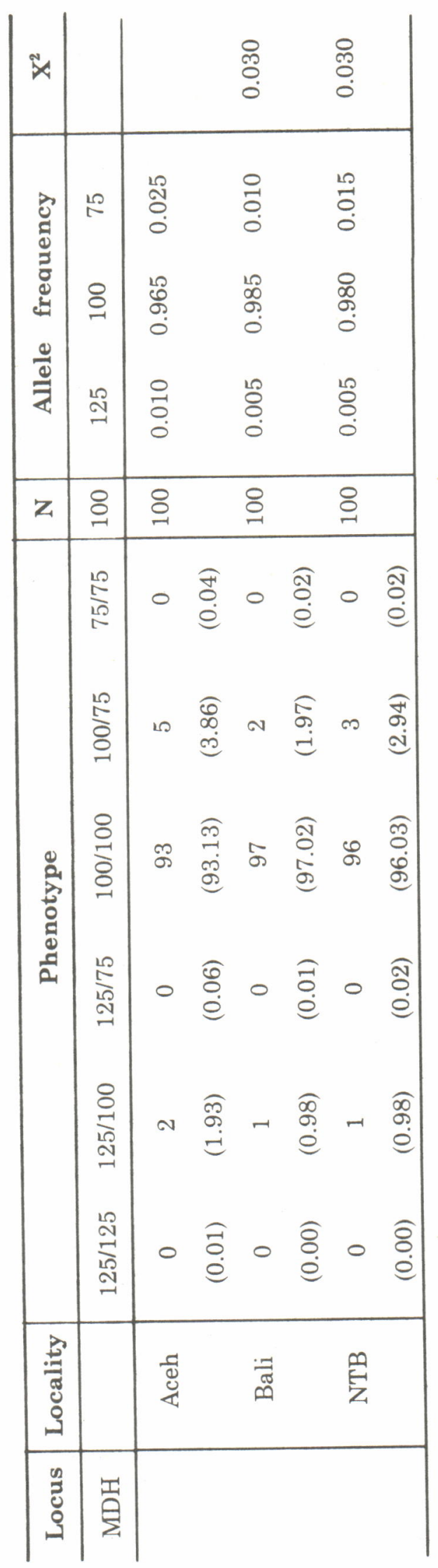




\section{Esterase (EST)}

Two anodal zones of EST activity were observed in the present study. They were assumed to represent the expression of two loci, designated EST-1 and EST-2. EST-1 was represented by a single variant zone expressed in hepatopancreas extracts only. Genetic interpretation was not attempted for the EST-1 locus, because of poor resolution. EST-2 was polymorphic in population samples and it was pressumed to be controlled by two alleles. The two-banded heterozygous type suggests a monomeric structure of the enzyme (Fig. 1).

\section{Glucosephosphate Isomerase (GPI)}

A single anodal zone was contained for this enzyme in abdominal muscle extracts. It was presumed as a single locus and was polymorphic. Heterozygous individuals showed a threebanded genotype while homozygous individuals showed a single-banded genotype indicating a dimeric structure for this enzyme which was presumed to be controlled by three alleles (Fig. $1)$.

\section{Isocitrate Dehydrogenase (IDH)}

This enzyme appeared in the anodal zone and was polymorphic in both samples exam. ined. A single locus was detected, presumed to be controlled by three alleles. Heterozygous individuals showed a three-banded genotype. Homozygous individuals showed a single banded genotype indicating a probable dimeric structure to the enzyme (Fig. 1).

\section{Lactate Dehydrogenase (LDH)}

This enzyme was represented by two zones of activity with different tissue predominance assumed to represent the expression of two loci. LDH-1 was muscle specific and LDH-2 was hepatopancreas spesific. Both appeared in the anodal zone. LDH-1 locus was polymorphic controlled by three alleles and was heterozy. gous. It was not clearly resolved under the electrophoretic conditions used, but it indicates a probable tetrameric structure for the enzyme (Fig. 1). This agrees with the findings of Sugama et al. (1988).

\section{Malate dehydrogenase (MDH)}

Two loci were detected in this enzyme MDH1 in the anodal zone and MDH-2 in the cathodal zone. MDH-1 was polymorphic and heterozygous. Individuals showed three-banded phenotypes indicating a probable dimeric structure of this enzyme (Fig 1).

\section{$\alpha$-Glycerophosphate dehydrogenase ( $\alpha$ - GPD)}

Polymorphic $\alpha$-GPD was detected in the muscle tissue. The band number of the heterozygous type was not clearly resolved under the electrophoretic conditions used but it suggests indicates a probable dimeric structure for the enzyme (Fig. 1). This agree with the findings of Sbordoni et al. (1986).

\section{- Genetic variability:}

The observed number of phenotypes and their Hardy-Weinberg expectations are given in Table 2. Result shows that the differences between observed numbers and their Hardy. Weinberg expectations were not significant at $\mathrm{P}<0.05$ for the respective polymorphic loci examined here (see $\mathrm{X}^{2}$ values in Table 2). These support the validity of the genetic models proposed for each polymorphism and indicate that the population samples of Penaeus monodon were collected from a single Mendelian population.

The average observed (Ho) and expected $(\mathrm{He})$ heterozygosities for Aceh, Bali and NTB $(\mathrm{Ho} / \mathrm{He})$ were $0.047 / 0.047,0.025 / 0.025$ and $0.028 / 0.026$ respectively. The number of allele per locus for Aceh, Bali and NTB were 1.528, 1.381 and 1.428 repectively. The value of heterozygosities $(\mathrm{H})$ and Number of allele per locus (N) of the Aceh sample were slighly higher than the other two samples. Average heterozygosity (Ho) observed is this study ranged from $0.025 \sim$ 0.047 , were comparable or slighly lower than 
those found by other researchers working with penaeid shrimp, such as Penaeus vannamei, $\mathrm{H}=0.02$ (Lester, 1983), Penaeus stylirostris $\mathrm{H}=$ 0.06 (Lester, 1983) and Penaeus japonicus (Sbordoni et al., 1986), $\mathrm{H}=0.039$. More comprehensive reviews reported hetero-zygosities of 0.048 for decapods (Hedgecock et al., 1982), and 0.082 for crustaceans (Nevo, 1984). Thus decapods and crustaceans including Penaeus monodon generally have a low level of genetic variability, as also found in the present study.

The allele frequency differences among localities were tested by Chi-square $\left(\mathrm{X}^{2}\right)$ test for heterogeneity (Crow and Kimura, 1970). Significant heterogeneity was observed at GPI-100 locus between Aceh and Bali $\left(\mathrm{X}^{2}=8,49 ; \mathrm{P}<0.01\right)$ and between Aceh and NTB $\left(\mathrm{X}^{2}=8.49 ; \mathrm{P}<0.01\right)$ but not between Bali and NTB $\left(X^{2}=0.001\right.$ $P>0.05$ ). Dispite a lack of large allele frequency differences among samples, apparent statistical significances at GPI locus indicated that the sample did not represent a single homogeneous gene pool.

The small allele frequency differences resulted in very low estimates of genetic divergence as measured by genetic distance (Nei, 1972). Genetic distance (D), i e: $D=0.00094$ for Aceh vs Bali, $D=0.00077$ for Aceh vs NTB and $\mathrm{D}=0.00004$ for Bali vs NTB.

The prime purpose of the present study has been to describe and interpret genetically a large number of electrophoretically detectable loci for the genetic population structure of shrimp and to find a genetic markers for the hatchery stock. Taniguchi et al. (1994) discussed the potentially valuable role of genetic markers in the development of advanced breeding schemes for fish directed toward genetic improvement of both wild and domesticated stocks. Recently, Goudie et al. (1995) reported that heterozygosity of the GPI locus was associated with growth in wild and domesticated populations of African catfish.

In the present study, the use of the polymor. phic loci (GPI, IDH and MDH) as a genetic marker has further advantages in that resolution of zymograms for those loci are good (Fig. 1). Therefore, the present findings suggest possibilities for the use of GPI, IDH and MDH as biochemical markers in genetic improvement programmes.

\section{REFERENCES}

Alledorf, F. W. and F. M. Utter. 1979. Population genetics In Fish Physiology. W. S. Hoar, D. J. Randalland J. R. Breet, (eds.) Acad. Press. New York. P. 407-454.

Avise, J. C. 1976. Genetic differentation during speciation In Molecular Evolution. Ayala, F. J. (eds.). Sinauer Associates, Masschusettes. p. 106122.

Benzie, J. A. H., S. Frusher, and E. Ballmen, 1975. Geographical variation in allozyme frequencies of populations of Penaeus monodon (Crustacea; Decapoda) in Australia, Aust. J. Mar. Freshwater Res., 43: 715-725.

Busack, C. S. 1988. Electrophoretic variation in thered swamp (Procamborus clarkii) and white crayfish $P$. acutus (Decapoda: Camboridae). Aquaculture 68:211-226.

Chamberlain. G. W. 1991. Shrimp farming in Indonesia-I growout technique. World Aquaculture, 22:12-27.

Crow, J. F. and M. Kimura. 1970. Introductions to population genetic theory. Harper and Row, New York, NY., $591 \mathrm{pp}$.

Goswani, U., S. G. Dalel and S. C. Goswani. 1986. Preliminary studies on prawn, Penaeus marguensis for selection of broodstock in genetic improvement program Aquaculture, 56: 41-48.

Goudie, C.A., Liu Q., Bill A.S. and Davis K.B., 1995. Genetic relationship of growth, sex and Glucophosfate isomerase-B phenotypes in Chamel catfish, Ichtalurus punctatus Aquaculture 138:119-124.

Hedgecock, D., M. L. Tracey and K. Nelson. 1982. Genetic In D. E. Bliss eds. The biology of crustacea vol 2. Embryology, Morphology and Genetics. Academic Press. New York. N.Y. pp. 283-403.

Lester, L. J. 1983. Developing a selective breeding program for penaeid shrimp marineculture. Aquaculture, 33:41-50.

Nei, M. 1972. Genetic distance between populations Am. Nat., 106: 283-292.

Nei M. 1975. Molecular Population Genetic and evolution. Ann. Hum. Genet. London, 41:225-233.

Nevo, E.T. A. Beiles and R. Benshlomo. 1984. The evolutionary significance of genetic diversity. In G. S. Mani (eds.) Evolutionary Dynamics of genetic diversity Vol. 53: 14-213.

Sbordoni, V., E. De Mattaeis, M. C. Sbordoni, G. La Rose, and M. Mattocia. 1986. Battlenect effects hatchery stock of Penaeus japonicus (Crustacea), Aquaculture, 57:239-251. 
Sokal, R. R and R. G. Rohlf. 1981. Biometry. Freeman and Co. San Francisco Calif., 776 pp.

Sugama. K. 1988. Population genetic analisis of red sea bream, Pagrus major. Master thesis Kochi University Japan. 81 pp.

Sugama K., N. Taniguchi and S. Seki. 1992. Survival growth and gonad development of triploid red sea bream. Aquaculture and Fisheries Management, $23: 149-159$.

Sugama K, Haryanti and Suko Ismi, 1993. Reproductive Performance of Penaeus monodon from Sumbawa, Madura and their Hybrids. J. Coastal Aqua. Res Indonesia. $9: 147-154$.
Taniguchi, N. and K. Sugama 1990. Genetic variation and population structure of sea bream in the coastal waters of Japan and in the East China sea. Nippon suisan Gakkaishi 56 : 1069-1077.

Taniguchi, N., H. S. Han and S. Tsujimura 1994. Variantion in some quantitative traits of cloned produce by chromosome manipulation in Plecoglossus altivelis. Aquaculture 120 : 53-60.

Wohlforth, G. W. and G. Hulata. 1983. Applied genetics of Tilapias. ICLARM studies and Review No. 6 International Center for Living Aquatic Resources Management Manila. The Philippines $26 \mathrm{pp}$. 